\title{
Effect of Different Levels of Irrigation and Nitrogen on Growth and Yield of Bt Cotton
}

\author{
S.G. Mahadevappa*, G. Sreenivas, D. Raji Reddy, A. Madhavi and S.S. Rao \\ Department of Agronomy, College of Agriculture, Professor Jayashankar Telangana State \\ Agricultural University, Rajendranagar, Hyderabad - 500 030, India \\ *Corresponding author
}

\begin{tabular}{|c|}
\hline $\begin{array}{l}\text { Ke y w o r d s } \\
\text { Irrigation, Nitrogen, } \\
\text { Cotton (Gossypium } \\
\text { hirsutum L.) }\end{array}$ \\
\hline Article Info \\
\hline $\begin{array}{l}\text { Accepted: } \\
\text { 26 July } 2018 \\
\text { Available Online: } \\
\text { 10 August } 2018\end{array}$ \\
\hline
\end{tabular}

\section{A B S T R A C T}

Field experiments were conducted during kharif 2014 and 2015 at Agricultural Research Institute, Rajendranagar to determine the optimum irrigation schedule and nitrogen level for Bt cotton in alfisols in Southern Telangana. Irrigation at 0.8 IW/CPE recorded significantly higher plant height $(97 \mathrm{~cm})$, drymatter at first picking $\left(220 \mathrm{~g}^{-1}\right.$ plant $\left.{ }^{-1}\right)$, bolls plant ${ }^{-1}(19)$, seed cotton yield $\left(1700 \mathrm{~kg} \mathrm{ha}^{-1}\right)$, lint yield $\left(626 \mathrm{~kg} \mathrm{ha}^{-1}\right)$, stalk yield $(2282 \mathrm{~kg}$ $\left.\mathrm{ha}^{-1}\right)$ and nitrogen uptake $\left(91 \mathrm{~kg} \mathrm{ha}^{-1}\right)$ and was not differed significantly with $0.4 \mathrm{IW} / \mathrm{CPE}$ and these were significantly superior to rainfed cotton. Among nitrogen levels, significantly higher plant height $(109 \mathrm{~cm})$, drymatter at first picking $\left(247 \mathrm{~g} \mathrm{plant}^{-1}\right)$ stage, days to reach boll development (94 days) stage, bolls plant ${ }^{-1}$ (19), boll weight (4.7 $\mathrm{g}$ ), seed index $(9.1 \mathrm{~g})$, seed cotton yield $\left(1700 \mathrm{~kg} \mathrm{ha}^{-1}\right)$, lint yield $\left(626 \mathrm{~kg} \mathrm{ha}^{-1}\right)$ and stalk yield (2282 $\mathrm{kg} \mathrm{ha}^{-1}$ ) were found with application of nitrogen at $225 \mathrm{~kg} \mathrm{ha}^{-1}$ was comparable with 150 $\mathrm{kg} \mathrm{N} \mathrm{ha}^{-1}$ and were significantly superior over lower levels of nitrogen application. The substantial increase in yield and yield attributes might be due to favorable effect on growth attributes like plant height, increased bolls plant ${ }^{-1}$, drymatter accumulation plant ${ }^{-1}$ and its subsequent translocation towards sink improved the seed cotton yield. It can be concluded that, higher seed cotton yield with higher net returns can be obtained with the irrigation scheduled at $0.4 \mathrm{IW} / \mathrm{CPE}$ and application of nitrogen at $150 \mathrm{~kg} \mathrm{ha}^{-1}$ in Bt cotton grown in alfisols.

\section{Introduction}

Cotton (Gossypium hirsutum L.), is one of the major cash crops of India, popularly known as 'White gold' and 'King of fibres' for its role in the national economy in terms of foreign exchange earnings and employment generation. It is estimated that, the global demand for cotton will be increasing from current levels of 25 million metric tons to 48 million metric tons by 2030 from 34 million hectares of the cultivated area of the world (FICCI, 2012). In India, cotton is grown in an area of 12.82 million ha with a production of 34.80 million bales and productivity of $462 \mathrm{~kg}$ lint $\mathrm{ha}^{-1}$, which is below the world's average of $790 \mathrm{~kg} \mathrm{ha}^{-1}$ during 2014-15 (www.indiastat.com). Telangana is a major cotton growing state cultivated in area of 1.71 million ha mostly under rainfed condition with a production of 3.80 million bales and productivity of the $377 \mathrm{~kg}$ lint $\mathrm{ha}^{-1}$ during 
2014-15 (www.indiastat.com). Many factors such as undependable monsoon, unsuitable soil, improper sowing time, non-adoption of recommended technologies especially fertilizer use are limiting cotton production at farmers' field (Ramasundaram and Hemachandra, 2001). Among these factors, marginal soils especially alfisols with shallow depth and low fertility status and; low rainfall with uneven distribution are the important factors affecting cotton growth, development and seed cotton yield. The cotton crop is generally grown in medium to deep black clayey soil, but in South Telangana Zone is mainly grown on shallow sandy and sandy loams with low water holding capacity and low nutrient status resulted in poor yields of rainfed cotton necessitates the proper irrigation planning to ensure adequate yields and reduce risks of production. Excessive use of nitrogen fertilizers leading to heavy pest incidence in certain pockets whereas in some areas it is below optimum mainly because of the risk associated with the investment under frequently failing crop environment. Water and nitrogen are the key inputs for improving the cotton productivity, which must be used in most efficient manner to sustain the cotton productivity at higher level. Moisture stress had adverse effect on yield as well as excess irrigation decreases the yield and increases the growing season (Wanjura et al., 2002 and Karam et al., 2006). Similarly nitrogen deficiency in cotton reduces vegetative and reproductive growth and induces premature senescence, there by potentially reduces the yields (Tewiodle and Fernandez 1997), where as high nitrogen availability may shift the balance between vegetative and reproductive growth towards excessive vegetative development thus delaying maturity. Since both irrigation and nitrogen are costly inputs, efficient utilisation of these resources through optimum synergistic combination is essential for higher productivity of $\mathrm{Bt}$ cotton grown in alfisols under less rainfall receiving areas of
South Telangana Zone. Hence, the present investigation was taken up to study the impact of different irrigation schedules and nitrogen levels on growth and yield of cotton.

\section{Materials and Methods}

The field experiment was carried out at Agricultural Research Institute, Professor Jayashankar Telangana State Agricultural University, Rajendranagar, Hyderabad during kharif seasons of 2014 and 2015 to determine the optimum irrigation schedule and nitrogen level for higher seed cotton yield. The experimental site was sandy loam in texture, neutral in reaction, low in available nitrogen, phosphorus and high in available potassium. The experiment was laid out in split plot design with three irrigation levels $\left(\mathrm{I}_{1}-0.8\right.$ IW/CPE, $\mathrm{I}_{2}-0.4 \mathrm{IW} / \mathrm{CPE}$ and $\mathrm{I}_{3}$ - Rainfed) as main plots and four nitrogen levels $\left(\mathrm{N}_{1^{-}} 0 \mathrm{~kg}\right.$ $\mathrm{ha}^{-1}, \mathrm{~N}_{2}-75 \mathrm{~kg} \mathrm{ha}^{-1}, \mathrm{~N}_{3}-150 \mathrm{kgha}^{-1}$ and $\mathrm{N}_{4}-$ $225 \mathrm{~kg} \mathrm{ha}^{-1}$ ) as sub plot treatments replicated thrice. The cotton cultivar Mallika BG II was sown at a spacing of $90 \mathrm{~cm} \mathrm{X} 60 \mathrm{~cm}$. A uniform dose of $60 \mathrm{~kg} \mathrm{ha}^{-1} \mathrm{P}_{2} \mathrm{O}_{5}$ as single super phosphate was applied to all the treatments as basal. Potassium @ $60 \mathrm{~kg} \mathrm{ha}^{-1}$ as muriate of potash was applied in four equal splits along with nitrogen fertilizer as top dressing. Nitrogen was applied as per the treatments (wherever it was required) in the form of urea $(46 \% \mathrm{~N})$ in four equal splits $\left(1 / 4^{\text {th }}\right.$ each at $20,40,60$ and 80 DAS). Irrigations were scheduled as per the treatments based on IW/CPE ratio with a depth of $50 \mathrm{~mm}$. Observations on plant height, occurrence of phenophases, drymatter production, yield attributes and yield were recorded. Test weight was expressed as seed index i.e., weight of 100 seeds. Nitrogen content analyzed from dried samples at first picking stage was multiplied by drymatter for calculating uptake and expressed in $\mathrm{kg} \mathrm{ha}^{-1}$. Net monetary returns were worked out for different irrigation and nitrogen levels. The 
data was analyzed statistically applying analysis of variance technique for split plot design. The significance was tested by ' $\mathrm{F}$ ' test (Snedecor and Cochron, 1967). Critical difference for examining treatment means for their significance was calculated at 5 per cent level of probability $(\mathrm{P}=0.05)$.

\section{Results and Discussions}

\section{Growth and yield attributes}

Irrigation at 0.8 IW/CPE recorded significantly higher plant height $(97 \mathrm{~cm})$, number of bolls plant ${ }^{-1}$ (19) and drymatter production at first picking $\left(220 \mathrm{~g} \mathrm{plant}^{-1}\right)$ and was not differed significantly with 0.4 IW/CPE and were significantly superior over rainfed cotton (Table 1). Irrigation schedules did not influence the boll weight and seed index however relatively higher boll weight and seed index was found with crop supplemented with irrigation water in addition to the rainfall.

The increase in plant height, drymatter production, number of bolls, boll weight and seed index with increased irrigation frequencies might be due to the increased moisture absorption along with nutrients resulted in greater cell elongation and turgidity (Dadgale et al., 2014) as well as increased photosynthesis by enabling the plant to trap higher quantity of radiant energy, increased translocation of photosynthates to the growing bolls, besides producing and retaining more number of bolls plant ${ }^{-1}$ at later stages of crop cycle (Ahlawat and Gangaiah, 2010, Bhunia, 2007 and Alse and Jadhav, 2011) resulted in higher drymatter production with irrigation scheduled at $0.8 \mathrm{IW} / \mathrm{CPE}$ and $0.4 \mathrm{IW} / \mathrm{CPE}$. Crop supplemented with 0.8 IW/CPE has taken significantly more number of days (94) to reach boll development stage. Whereas, soil moisture deficit under rainfed situation might have reduced cell elongation, low photosynthesis and carbohydrate synthesis which resulted in lower drymatter production (Dadgale et al., 2014).

Among nitrogen levels, significantly higher plant height $(109 \mathrm{~cm})$, drymatter production at first picking (247 $\mathrm{g} \mathrm{plant}^{-1}$ ) stage, days to reach boll development (94 days) stage, number of bolls plant ${ }^{-1}$ (19), boll weight (4.7 $\mathrm{g})$ and seed index (9.1 g) were found with application of nitrogen at $225 \mathrm{~kg} \mathrm{ha}^{-1}$ was comparable with $150 \mathrm{~kg} \mathrm{ha}^{-1}$ and were significantly superior over lower levels of nitrogen application (Table 1). The increase in plant height might be due to favorable effect of nitrogen on growth, development and drymatter production of cotton as reported by Gundlur et al., (2013) and Sunitha et al., (2010). However because of more vegetative growth causes delay in maturity i.e., it has taken more number of days to reach boll development stage at higher levels of nitrogen application. Similar results were reported by Howard et al., (2001), Dong et al., (2012) and Munir et al., (2015).

\section{Yield}

Significantly higher seed cotton yield (1700 $\left.\mathrm{kg} \mathrm{ha}^{-1}\right)$, lint yield $\left(626 \mathrm{~kg} \mathrm{ha}^{-1}\right)$ and stalk yield $\left(2282 \mathrm{~kg} \mathrm{ha}^{-1}\right)$ was obtained at $0.8 \mathrm{IW} / \mathrm{CPE}$, which was at par with 0.4 IW/CPE and significantly superior over rainfed cotton, which registered $1201 \mathrm{~kg} \mathrm{ha}^{-1}$ of seed cotton yield, $437 \mathrm{~kg} \mathrm{ha}^{-1}$ of lint yield and $1595 \mathrm{~kg} \mathrm{ha}^{-1}$ of stalk yield (Table 2). The higher seed cotton yields with 0.8 IW/CPE and 0.4 IW/CPE might be resulted from greater nutrient uptake in the favorable regime of soil moisture leads to balanced vegetative growth, higher drymatter production, increased number of bolls plant ${ }^{-1}$ which ultimately reflected in seed cotton yield. These observations confirm the findings of Dhadgale et al., (2014), Shinde et al., (2009) and Bandyopadhyay et al., (2009). 
Table.1 Effect of varied levels of irrigation schedules and nitrogen levels on plant height, phenology and yield attributes of Bt cotton (Pooled)

\begin{tabular}{|c|c|c|c|c|c|c|}
\hline Treatments & $\begin{array}{l}\text { Plant } \\
\text { height } \\
(\mathrm{cm})\end{array}$ & $\begin{array}{l}\text { Days to boll } \\
\text { development } \\
\text { (No.) }\end{array}$ & $\begin{array}{c}\text { Drymatter } \\
\text { production } \\
\text { at first } \\
\text { picking } \\
\end{array}$ & $\begin{array}{l}\text { Bolls } \\
\text { plant }^{-1} \\
\text { (No.) }\end{array}$ & $\begin{array}{l}\text { Boll } \\
\text { weight } \\
\text { (g) }\end{array}$ & $\begin{array}{l}\text { Seed } \\
\text { index } \\
(\mathrm{g})\end{array}$ \\
\hline \multicolumn{7}{|l|}{ Irrigation (I) } \\
\hline $\mathrm{I}_{1}$ - $0.8 \mathrm{IW} / \mathrm{CPE}$ & 97 & 94 & 218 & 19 & 5.1 & 9.7 \\
\hline $\mathrm{I}_{2}-0.4 \mathrm{IW} / \mathrm{CPE}$ & 96 & 93 & 207 & 17 & 5.1 & 9.6 \\
\hline$I_{3}$ - Rainfed & 89 & 93 & 161 & 14 & 4.8 & 9.3 \\
\hline S. Em & - & - & 3.2 & 0.67 & 0.07 & 0.2 \\
\hline CD $(p=0.05)$ & 6.8 & 0.25 & 12.6 & 2.61 & NS & NS \\
\hline \multicolumn{7}{|l|}{ Nitrogen $(\mathbf{N})$} \\
\hline $\mathrm{N}_{1}-0 \mathrm{~kg} \mathrm{ha}^{-1}$ & 78 & 92 & 138 & 13 & 4.7 & 9.1 \\
\hline$N_{2}-75 \mathrm{~kg} \mathrm{ha}^{-1}$ & 92 & 93 & 180 & 17 & 5.0 & 9.5 \\
\hline $\mathrm{N}_{3}-150 \mathrm{~kg} \mathrm{ha}^{-1}$ & 102 & 93 & 224 & 19 & 5.2 & 9.6 \\
\hline $\mathrm{N}_{4}-225 \mathrm{~kg} \mathrm{ha}^{-1}$ & 109 & 94 & 239 & 19 & 5.2 & 9.8 \\
\hline S. Em \pm & - & - & 5.6 & 0.37 & 0.08 & - \\
\hline$C D(p=0.05)$ & 7.6 & 0.48 & 16.5 & 1.1 & 0.23 & 0.49 \\
\hline \multicolumn{7}{|c|}{ Interaction (I X N) } \\
\hline $\mathrm{CD}(\mathrm{p}=0.05)$ & NS & NS & NS & NS & NS & NS \\
\hline
\end{tabular}

Table.2 Effect of varied levels of irrigation schedules and nitrogen levels on yield, nitrogen uptake and economics of Bt cotton (Pooled)

\begin{tabular}{|c|c|c|c|c|c|}
\hline Treatments & $\begin{array}{c}\text { Seed cotton } \\
\text { yield }\left(\mathrm{kg} \mathrm{ha}^{-1}\right)\end{array}$ & $\begin{array}{l}\text { Lint Yield } \\
\left(\mathrm{kg} \mathrm{ha}^{-1}\right)\end{array}$ & $\begin{array}{l}\text { Stalk Yield } \\
\left(\mathrm{kg} \mathrm{ha}^{-1}\right)\end{array}$ & $\begin{array}{l}\text { N uptake } \\
\left(\mathrm{kg} \mathrm{ha}^{-1}\right)\end{array}$ & $\begin{array}{l}\text { Net returns } \\
(\text { Rs. ha }\end{array}$ \\
\hline \multicolumn{6}{|l|}{ Irrigation (I) } \\
\hline $\mathrm{I}_{1}-0.8 \mathrm{IW} / \mathrm{CPE}$ & 1700 & 626 & 2282 & 91 & 21807 \\
\hline $\mathrm{I}_{2}-0.4 \mathrm{IW} / \mathrm{CPE}$ & 1524 & 562 & 2264 & 83 & 15710 \\
\hline$I_{3}$ - Rainfed & 1201 & 437 & 1595 & 61 & 6816 \\
\hline S. Em \pm & 48 & 17.1 & 81 & 2.1 & 1037 \\
\hline$C D(p=0.05)$ & 188 & 67 & 317 & 8.4 & 4073 \\
\hline \multicolumn{6}{|l|}{ Nitrogen (N) } \\
\hline$N_{1}-0 \mathrm{~kg} \mathrm{ha}^{-1}$ & 977 & 353 & 1436 & 48 & 463 \\
\hline $\mathrm{N}_{2}-75 \mathrm{~kg} \mathrm{ha}^{-1}$ & 1506 & 547 & 1914 & 59 & 17358 \\
\hline $\mathrm{N}_{3}-150 \mathrm{~kg} \mathrm{ha}^{-1}$ & 1704 & 630 & 2354 & 100 & 21543 \\
\hline $\mathrm{N}_{4}-225 \mathrm{~kg} \mathrm{ha}^{-1}$ & 1714 & 636 & 2484 & 107 & 19745 \\
\hline S. Em & 57 & 19.2 & 48 & 2.7 & 1655 \\
\hline $\mathrm{CD}(\mathrm{p}=0.05)$ & 171 & 57 & 142 & 7.9 & 4919 \\
\hline \multicolumn{6}{|c|}{ Interaction (I X N) } \\
\hline $\mathrm{CD}(\mathrm{p}=0.05)$ & NS & NS & NS & NS & NS \\
\hline
\end{tabular}


Significantly higher seed cotton yield (1714 $\left.\mathrm{kg} \mathrm{ha}{ }^{-1}\right)$, lint yield $\left(636 \mathrm{~kg} \mathrm{ha}^{-1}\right)$ and stalk yield (2484 $\mathrm{kg} \mathrm{ha}^{-1}$ ) were obtained with application of nitrogen at $225 \mathrm{~kg} \mathrm{ha}^{-1}$ and was comparable with $150 \mathrm{~kg} \mathrm{ha}{ }^{-1}$. Further, significantly lower seed cotton yield $(977 \mathrm{~kg}$ $\left.\mathrm{ha}^{-1}\right)$, lint yield $\left(353 \mathrm{~kg} \mathrm{ha}^{-1}\right)$ and stalk yield $\left(1436 \mathrm{~kg} \mathrm{ha}^{-1}\right)$ was registered with no nitrogen over higher levels of nitrogen application (Table 2). The substantial increase in seed cotton, lint and stalk yield due to application of higher levels of nitrogen might be due to favorable effect of nitrogen on growth attributes like plant height, increased number of bolls plant ${ }^{-1}$, drymatter accumulation plant $^{-1}$ and its subsequent translocation towards sink improved the seed cotton yield. Similar positive response of nitrogen on seed cotton yield was observed by Basavanneppa (2005) and Meena et al., (2007).

\section{Nitrogen uptake}

Significantly higher nitrogen uptake $(91 \mathrm{~kg}$ $\mathrm{ha}^{-1}$ ) was recorded with irrigation scheduled at $0.8 \mathrm{IW} / \mathrm{CPE}$ was comparable to 0.4 IW/CPE with nitrogen uptake of $83 \mathrm{~kg} \mathrm{ha}^{-1}$ at first picking stage and were significantly superior over rainfed cotton $\left(61 \mathrm{~kg} \mathrm{ha}^{-1}\right)$. Among nitrogen levels, significantly higher nitrogen uptake $\left(107 \mathrm{~kg} \mathrm{ha}^{-1}\right)$ was found with application of nitrogen at $225 \mathrm{~kg} \mathrm{ha}^{-1}$ and was did not differ significantly with $150 \mathrm{~kg}$ nitrogen ha ${ }^{-1}$ which registered $100 \mathrm{~kg} \mathrm{ha}^{-1}$ of nitrogen uptake and were significantly superior over lower levels of nitrogen application (Table 2).

The increased uptake of nitrogen might be due to favourable soil moisture and nitrogen availability in the soil at higher levels of application increases plant height, boll number, boll weight and increased drymatter production. These findings were in close agreement with those obtained by Modhvadia et al., (2012).

\section{Economics}

Higher net returns were realized at 0.8 IW/CPE was comparable with 0.4 IW/CPE and superior over rainfed cotton, which recorded significantly lower net returns (6816 Rs. ha $^{-1}$ ).

Significantly higher net returns were obtained at higher levels of nitrogen application over no nitrogen application (Table 2).

From the experiment, it can be concluded that, higher seed cotton yield with higher net returns can be obtained with the irrigation scheduled at $0.4 \mathrm{IW} / \mathrm{CPE}$ and application of nitrogen at $150 \mathrm{~kg} \mathrm{ha}^{-1}$ in Bt cotton grown in alfisols.

\section{References}

Ahlawat, I. P. S and Gangaiah, B. 2010. Response of Bt cotton (Gossypium hirsutum) hybrids to irrigation. Indian Journal of Agricultural Sciences 80 (4): 271-274

Alse, U. N and Jadhav, A. S. 2011. Agronomic efficency of Bt and Non Bt cotton hybrids under irrigated conditions. Journal of Cotton Research and Development. 25 (1): 38-41

Bandyopadhyay, K. K., Prakash, A. H., Sankaranarayanan, K., Dharajothi, B and Gopalakrishnan, N. 2009. Effect of irrigation and nitrogen on soil water dynamics, productivity and inputuse efficiency of $B t$ cotton (Gossypium hirsutum) in a Vertic Ustropept. Indian Journal of Agricultural Sciences 79 (6): $448-453$.

Basavanneppa, M. A., Angadi, V.V and Biradar, D.P. 2015. Productivity and endotoxin expression as influenced by nutrient levels and nitrogen doses application in $B t$ cotton under irrigation. Journal of Cotton Research and Development 29 (1) 39-44.

Bhunia, S. R. 2007. Effect of methods of irrigation and levels of phosphorus on desi cotton (Gossypium arboreum) in shallow 
water-table condition. Journal of Cotton Research and Development 21(2): 184-186.

Dadgale, P. R., Chavan, D. A., Gudade, B. A., Jadhav, S. G., Deshmukh, V. A and Suresh Pal. 2014. Productivity and quality of Bt cotton (Gossypium hirsutum) as influenced by planting geometry and nitrogen levels under irrigated and rainfed conditions. Indian Journal of Agricultural Sciences 84 (9): 1069-1072

Dong, H., Li, W., Eneji, A.E and Zhang, D. 2012. Nitrogen rate and plant density effects on yield and late season leaf senescence of cotton raised on a saline field. Field Crops Research. 126: 137-144.

FICCI, 2012. Cotton 2020 Roadmap for sustainable production. February 01, 2012 New Delhi.

Gundlur, S.S., Rajkumara, S., Neelakanth, J.K., Ashoka, P and Khot, A.B. 2013. Water and nutrient requirement of $\mathrm{Bt}$ cotton under vertisols of Malaprabha command. Karnataka Journal of Agricultural Sciences, 26 (3): 368-371.

Howard, D.D., Gwathmey, C.O., Essington, M.E., Roberts, R.K and Mullen, M.D. 2001. Nitrogen fertilization of no-till cotton on loess- derived soils. Agronomy Journal. 93: 157-163.

Karam, F., Randa, M., Daccache, A., Mounzer, O and Rouphael, Y 2006. Water use and lint response of drip irrigated cotton to length of season. Agricultural Water Management 85(3): 287-295.

Meena, R. L., Babu, V. R and Nath, A 2007. Effect of fertilizer management on cotton under saline soils of Gujarat. Bharatiya Krishi Anusandhan Patrika 22: 206-210.

Modhvadia, J. M., Solanki, R. M., Nariya, J. N., Vadaria, K. N and Rathod, A. D 2012. Effect of different levels of nitrogen, phosphorus and potassium on growth, yield quality of Bt cotton hybrid under irrigated conditions. Journal of Cotton Research and Development. 26 (1) : 47-51

Munir, M.K., Tahir, M., Saleem, M.F and Yaseen, M. 2015. Growth, yield and earliness response of cotton to row spacing and nitrogen management. The Journal of Animal and Plant Sciences. 25(3): 729-738.

Pandagale, A. D., Khargkharate, V. K., Kadam, G. L and Rathod, S. S. 2015. Response of Bt cotton (Gossypium hirsutum L.) to varied plant geometry and fertilizer levels under rainfed condition. Journal of Cotton Research and Development 29 (2) 260-263.

Ramasundaram and Hemachandra 2001. Constraints to cotton production in India. CICR Technical Bulletin No: 19.

Shinde, V. S., Deshmukh, L. S and Raskar, S. K. 2009. Response of cotton (Gossypium arboreum L.) to protective irrigation at different critical growth stages. Journal of cotton Research and Development 23 (1): 93-95.

Snedecor, G. W and Cochron, W. G. 1967. Statistical Methods. Oxford and IBH Publishing company 17, Parklane, Calcutta. 172-177.

Sunitha, V., Chandra Sekhar, K and Veera Raghavaiah, R. 2010. Performance of $\mathrm{Bt}$ cotton hybrids at different nitrogen levels. Journal of Cotton Research and Development. 24 (1) : 52-55

Tewiodle and Fernadez, C. J 1997. Vegetative and reproductive dry weight inhibition in nitrogen and phosphorus deficient Pima cotton. Indian Jiurnal of Agronomy (38)4: 609-612.

Wanjura, D, F., Upchurch, D. R., Mahan, J. R and Burke, J. J. 2002. Cotton yield and applied water relationships under drip irrigation. Agricultural Water Management 55(3): 217-237.

\section{How to cite this article:}

Mahadevappa, S.G., G. Sreenivas, D. Raji Reddy, A. Madhavi and Rao, S.S. 2018. Effect of Different Levels of Irrigation and Nitrogen on Growth and Yield of Bt Cotton. Int.J.Curr.Microbiol.App.Sci. 7(08): 4599-4604. doi: https://doi.org/10.20546/ijcmas.2018.708.485 